\title{
Pelos bons serviços prestados e em razão do amor que lhe tenho: estratégias de luta dos escravos pela conquista da alforria em Rio Grande (1820-1860)
}

\author{
Fernando Lucas Garcia de Souza ${ }^{1}$
}

\begin{abstract}
Resumo: Este artigo pretende discutir as estratégias utilizadas pelos escravos para alcançar a liberdade através da manumissão no município de Rio Grande, na Província de São Pedro do Rio Grande do Sul, entre os anos de 1820 a 1860. Para tanto, utilizamo-nos das fontes disponíveis no Acervo dos Tabelionatos de municípios do interior do Rio Grande do Sul e do diálogo com autores que discutem o tema em outras localidades no mesmo século.
\end{abstract}

Palavras-chave: Escravidão, Alforria, Rio Grande.

\begin{abstract}
This article discusses the various strategies used by slaves to reach freedom through manumission in Rio Grande, Province of São Pedro do Rio Grande do Sul, between 1820 to 1860 's. Therefore, we used the sources available in the Acervo dos Tabelionatos de municipios do interior do Rio Grande do Sul and dialogue with authors who discuss the topic in other locations in the same century.
\end{abstract}

Keywords: Slavery, Manumission, Rio Grande.

\section{Introdução}

A prática da manumissão ou alforria caracteriza-se pela libertação de um sujeito da condição de escravo e a sua transformação em liberto. Esta possibilidade era geralmente atingida por meio da formação do pecúlio $^{2}$ por parte do escravo, objetivando a compra de sua liberdade. Porém, a autocompra não era a única maneira de o sujeito escravizado ser alforriado.

As fontes consultadas ${ }^{3}$ e os autores ${ }^{4}$ com os quais procuramos estabelecer diálogos mostram que várias foram as estratégias das quais os escravos se utilizaram para a conquista da alforria, as quais incluíam além do citado acúmulo integral do pecúlio; a renegociação de seu valor

1 Mestrando em História pela Universidade Federal da Grande Dourados - UFGD. E-mail: fernandogarcia.historia@gmail.com

2 O dicionário Michaelis define como pecúlio: 1 Reserva de dinheiro disponível que uma pessoa acumula aos poucos, como resultado de seu trabalho e economia. 2 Reserva de dinheiro. 3 Bens, patrimônio. 4 Conjunto de notícias ou apontamentos que dizem respeito a certo assunto ou especialidade. 5 Complexo de conhecimentos sobre certos assuntos. 6 Coleção valiosa. Fonte: http://michaelis.uol.com.br/moderno/portugues/

3 Livros de número 7, 10, 12, 13,14 e 17 do Fundo Tabelionato de Município de Rio Grande, disponíveis no Acervo dos Tabelionatos de municípios do interior do Rio Grande do Sul.

4 Especialmente Campos (2006), Carneiro da Cunha (2009), Freire (2011), Goldsmith (2010), Marquese (2000), Motta \& Lopes (2015), e Pires (2006). 
estabelecido pelo senhor, diante da dificuldade por parte do escravo de acumular ganhos; a alforria condicionada; a alforria concedida mediante parcelamento, na qual o senhor alforriava o escravo sob a condição de que este lhe pagasse o valor restante após a libertação; o pagamento parcial ou integral na forma de bens e mercadorias ou mesmo pela compra de outro escravo que o substituísse; a compra de sua liberdade por parte de um familiar ou outra pessoa a qual o escravo comumente ficaria obrigado por um intervalo de tempo; e a concessão gratuita da liberdade por parte dos senhores. Procuraremos adiante nos ater mais detalhadamente a cada uma dessas formas de manumissão.

\section{A formação do pecúlio}

Prática silenciada em lei até 1871, porém costumeira no sistema escravista brasileiro, a possibilidade do escravo de acumular pecúlio é percebida tanto nas fontes consultadas quanto nos autores com os quais dialogamos. Freire, ao analisar a região de Juiz de Fora (MG) no século XIX, escreve sobre o pecúlio:

Certamente os escravos tiveram possibilidades de obter para si e suas famílias, por meio de sua atuação, ganhos dentro do sistema escravista, sempre oscilando entre a autonomia e a dependência (FREIRE, 2011, p.213).

De modo semelhante, a pesquisa de Pires, centrada no alto sertão da Bahia no século XIX, especialmente as regiões de Rio das Contas e Caetité, revela a atuação dos escravos na economia informal. Entre os anos de 1870 e 1880, a autora analisou 407 alforrias, concluindo que 33 por cento dos escravos obtiveram suas cartas com pecúlio. Pires aponta ainda que a maneira de formar pecúlio relacionava-se diretamente aos arranjos cotidianos, que se constituíam nas redes de vizinhança e parentesco:

Os escravos do alto sertão realizavam pequenos negócios, prestavam serviços diversos, vendiam mantimentos nas feiras, conseguiam empréstimos, trabalhavam nas tropas ou como artífices nas oficinas manufatureiras das vilas (PIRES, 2006, p.156).

Em sua pesquisa sobre as alforrias em Vitória no século XIX, Campos também aponta a possibilidade da acumulação financeira por parte do escravo, destacando que "o pecúlio, portanto, era um instrumento comumente utilizado na Comarca de Vitória, mesmo antes da Lei de 1871" (CAMPOS, 2006, p.2). 
Entre as fontes que analisamos para este trabalho, é comum a verificação de alforrias concedidas mediante pagamento do valor estipulado, como pode ser percebido na alforria da escrava Maria, filha de Catarina, na qual se lê que "a carta foi concedida mediante o pagamento de 1 dobla $^{5}$, "atendendo aos bons serviços, e as súplicas, que me tem feito minha escrava Catarina [...] sou servida conceder a última filha que a minha escrava teve e por ora batizada em casa com o nome de Maria, esta carta de plena liberdade"(RIO GRANDE DO SUL, 2006, p.658). A formação do pecúlio por parte dos escravos aponta, portanto, para a atividade profissional destes sujeitos e sua participação no mundo do trabalho, para além da mera condição objetificada e inerte à qual a historiografia por vezes lhes condenou. Como problematiza Silvia Lara:

...os historiadores apagaram da história social do trabalho no Brasil a "nódoa" da escravidão. [...] Passaram a ser vistos como uma massa de trabalhadores nacionais indolentes e apáticos (na visão dos teóricos do final do século XIX) ou de anômicos e desajustados à modernidade do capitalismo, despreparados para o trabalho livre devido a experiência da escravidão (LARA, 1998, p.36).

Esta visão tradicional contestada por Lara é também contraposta por Pires, que analisando a inserção dos escravos em atividades profissionais como as de ferreiro, lavradores, costureiras, cozinheiras, alfaiates e vaqueiros, no sertão da Bahia, apontou estes sujeitos como ativos, que buscaram não apenas a liberdade, bem como a sua inserção na vida local, construída por meio do trabalho:

As cartas de liberdade e os autos criminais revelam 'arranjos', negociações, meios diversos de que os escravos lançaram mão para se livrarem do cativeiro, de modo que a abolição, ao chegar, encontrou mulheres e homens muito inseridos na vida local, com laços estreitos de vizinhança e, também, senhores ainda muito apegados à manutenção de suas prerrogativas senhoriais, outros mais atentos à instabilidade de uma relação social que rumava para o fim (PIRES, 2006, p.167, grifo nosso).

\section{As negociações de valor}

Segundo Pires, "em diversas partes do Brasil, os escravos, ao comprarem suas alforrias, insistiam na concessão, negociavam os preços e construíam criativamente estratégias para que

5 Uma Dobla equivale a $12 \$ 800$ réis. 
fossem concedidas" (PIRES, 2006, p.162).

Essa necessidade da negociação do valor de alforria pode ser entendida a partir de Motta e Lopes, que citam que "os escravos eram relativamente caros, e especialmente caros, decerto, quando seu preço era comparado ao ritmo possível de formação do pecúlio pelos próprios cativos, ao menos para a grande maioria deles" (MOTTA \& LOPES, 2015, p.13). Portanto, o preço definido pelos senhores e a dificuldade do escravo em acumular poupança, dada sua condição de exploração, somados ao desejo de liberdade, explicariam a constante negociação entre senhores e escravos pelo valor da alforria.

Mesmo após a regulamentação do pecúlio em 1871, a negociação do valor entre senhor e escravo para o acerto do preço permaneceu privativa das partes, sofrendo interferência da Justiça apenas em casos de impasse ${ }^{6}$. Esta prerrogativa abria espaço de negociação ao escravo, ao passo que também se desenrolou nas mais diversas imposições por parte dos senhores, como veremos mais adiante.

\section{A alforria condicionada}

As fontes analisadas nos revelaram outra forma distinta de concessão da alforria, a alforria condicionada. Nestes casos, o senhor concedia a alforria "gratuitamente" ou mediante pagamento acertado, porém o escravo não se via imediatamente livre de suas obrigações. Por vezes, a conquista da liberdade era condicionada a espera, a obrigação de continuar servindo ao senhor até a morte deste, ou até mesmo a extensão desta obrigação ao cônjuge e filhos do senhor, como percebemos na manumissão dos escravos João, Eva e Bárbara:

João; Benguela; Sr. Joaquim José de Souza; dt. conc. 02-07-28; dt. reg. 2911-28; da Freguesia de São Francisco de Paula (10 léguas de Rio Grande) (Livro 10, p. 46r). Desc.: A carta foi concedida com a condição do escravo servir até a morte do senhor, em retribuição aos bons serviços prestados há 30 anos. O senhor pediu a Salvador Bueno da Boa Nova que a fizesse. (RIO GRANDE DO SUL, 2006, p.658, grifo nosso)

Eva; preta; 5; Sra. Juliana Bueno de Morais (casada com Salvador Bueno da Boa Nova); dt. conc. 02-05-28; dt. reg. 29-11-28 (Livro 10, p. 47r). Desc.: A carta foi concedida com a condição de a escrava servir até a morte da senhora, sendo que estava avaliada pela senhora e seu marido em 5 doblas, "a custa do terço" da alma de sua senhora, e caso esta falecesse antes da cativa completar 25 anos, a escrava teria como seu tutor o marido da senhora, e se este também falecesse, o afilhado, Ricardo Pinto de Morais.

$6 \quad$ Ver página 13. 
Os senhores eram moradores na Freguesia de São Francisco de Paula, 10 léguas de Rio Grande. A senhora pediu a Teotônio José Lopes que a fizesse e assinasse a rogo. (RIO GRANDE DO SUL, 2006, p.658, grifo nosso)

Bárbara; Rita (sua mãe, da Costa, escrava da mesma senhora); Sra. Rita Maria de Alcântara; dt. conc. 29-02-16; dt. reg. 30-04- 29; da Freguesia da Nossa Senhora da Conceição de Canguçu (Livro 10, p.81r). Desc.: A carta foi concedida com a condição da escrava servir até a morte da senhora, "em atenção ao amor" que a mesma lhe tinha. Por não saber escrever, a senhora pediu a Domingo da Boa Nova que a fizesse e assinasse a rogo (RIO GRANDE DO SUL, 2006, p.658, grifo nosso).

A imposição destas condições revela muito mais uma estratégia de dominação senhorial sobre os escravos do que a benevolência do ato de alforria. Longe de ser gratuita, Mattoso nos mostra que a alforria condicionada custava muito caro ao escravo, sendo sempre revogável, acirrando a dependência do escravo, que ao menor sinal de desavença, um instante de mau humor, poderia significar o fim de sua futura libertação (Mattoso apud. Pires, 2006, p.147).

Neste sentido, nos chamou a atenção a diversidade das imposições senhoriais, que além da obrigação de servidão até a morte dos senhores, incluíam condições de naturezas diversas, como a alforria do escravo Tobias, condicionada à obrigação de acompanhar seu senhor em uma viagem à Inglaterra:

Tobias; preto, Mina; Sr. João Valentim Hall; dt. conc. 28-05-50, dt. reg. 0106-50 (Livro 17, p. 41v). Desc. A carta foi concedida com a condição do escravo acompanhar o senhor em uma viagem à Liverpool (RIO GRANDE DO SUL, 2006, p.665, grifo nosso).

Em outro fragmento analisado, a libertação da escrava Amélia estava atrelada, além da obrigação de "boa conduta" de sua continuidade junto à senhora enquanto esta vivesse, à ameaça do cativeiro de seus futuros filhos:

Amélia; parda, 1; Sra. Ana Monteiro; dt. conc. 02-01-50; dt. reg. 20-12-50 (Livro 17, p. 47r). Desc.: A carta foi concedida "por minha livre vontade sem constrangimento algum, a deixo livre, por minha morte, para sempre; outro sim declaro que, se a conduta da mencionada minha escrava Amélia, não for boa durante a minha vida, todos os filhos que ela tiver serão escravos" (RIO GRANDE DO SUL, 2006, p.665, grifo nosso).

Segundo Robert Slenes, no assédio às mulheres escravas, os senhores podiam oferecer liberdade ou estabilidade na fazenda, acompanhada da liberdade de trabalhos pesados ou a venda em separado de membros da família (1997, p.287-288). Neste sentido, observemos a alforria da 
escrava Anastácia, condicionada à obrigação de se casar com Antônio Araújo de Oliveira, seu senhor:

Anastácia; preta; Crioula; Sra. (sic) Antônio Araújo de Oliveira; dt. reg. 1805-29 (Livro 10, p. 83r). Desc.: A carta foi concedida "com o fim de que esta minha escrava case comigo conforme manda a Santa Madre Igreja Romana, no Caso que ela não queira receber-se comigo em Matrimônio ficará este papel de alforria de nenhum vigor e ela dita escrava ficará minha cativa como antes, e para clareza declaro que deixo livre ao arbitrio da minha dita escrava a sua vontade e que nisto não haja constrangimento algum, pois só quero contrair com ele o matrimônio sendo de sua própria e livre vontade". A escrava havia sido comprada de Joaquina Bueno por $250 \$$. Por não saber escrever, o senhor pediu a Francisco Moreira do Vale que fizesse a carta e assinasse como testemunha. (RIO GRANDE DO SUL, 2006, p.659, grifo nosso).

O trecho analisado revela a complexidade das relações e das estratégias, tanto de luta pela liberdade por parte dos escravos, quanto de dominação senhorial. Visto que a cessão da alforria objetivava a união matrimonial, sugerindo a carta haver o consenso entre as partes: "deixo livre ao arbítrio da minha dita escrava a sua vontade e que nisto não haja constrangimento algum, pois só quero contrair com ele (sic) o matrimônio sendo de sua própria e livre vontade", a condição imposta põe em dúvida a livre vontade da escrava em casar-se com seu senhor: "no Caso que ela não queira receber-se comigo em Matrimônio ficará este papel de alforria de nenhum vigor e ela dita escrava ficará minha cativa como antes".

\section{O parcelamento da alforria}

Ao discutir as estratégias de negociação dos escravos em busca da manumissão, Pires aponta que entre as alternativas de negociação, por vezes as alforrias se organizavam em prestações ou pagamentos parcelados, contando os escravos com a confiança de seus senhores, que deveriam esperar pelo pagamento a prazo. ${ }^{7}$

No mesmo sentido, Goldsmith também aponta o parcelamento como estratégia presente nas negociações entre senhores e escravos, nos casos das escravas Rita e Inácia:

Outro procedimento aceitável era parcelar o pagamento e um certo Agostinho Delgado de Arouche libertou sua escrava Rita, de cinquenta anos de idade, e explicou os motivos: "tanto por haver dado por si $30 \$ 000$ réis, a saber $25 \$ 600$ réis que já recebi em dinheiro de contado e $4 \$ 400$ que me fica devendo, como por ter dado de mamar a dois filhos meus" (GOLDSMITH,

7 Cf. PIRES, 2006, p.162. 
2010, p.118).

Já o senhor Inácio da Costa concordou que sua escrava Inácia fosse "pagando conforme puder", no decurso de seis anos, os $80 \$ 000$ réis estipulados para a sua libertação. Além disso, "para ajuda de sua liberdade", lhe consignou dois dias da semana "para trabalhar para si" e os mais para ele, "até acabar de pagar os ditos $80 \$ 000$ réis" (GOLDSMITH, 2010, p.118).

Esta forma de negociação pode ser percebida também nas alforrias Sul-Rio-Grandenses, como é o caso da escrava Catarina, alforriada ao pagar pouco menos de 50 por cento do valor estipulado por sua senhora, conseguindo o prazo de seus meses para o pagamento restante:

Catarina; Rebolo; Sra. Rita Maria de Alcântara; dt. conc. 16-07-28; dt. reg. 13-09-28; da Freguesia de Canguçu (Livro 10, p. 32r). Desc.: A carta foi concedida mediante o pagamento, pela escrava, de 64\$, sendo "que ao fazer esta recebi $25 \$ 600$, ficando-me a dita [escrava] restando a quantia de $38 \$ 400$ para me ir pagando quando lhe seja possivel da fatura desta, até o prazo de 6 meses". Em remuneração ao zelo e prontidão com que a escrava "constantemente" serviu a senhora. Por não saber ler nem escrever, a senhora pediu a João Pereira de Medeiros que a fizesse e assinasse a rogo (RIO GRANDE DO SUL, 2006, p.658, grifo nosso).

Como discutido por Pires e Goldsmith, essas possibilidades podem ser lidas como resultado das estratégias de negociação dos escravos em busca da manumissão, sobretudo em vista da dificuldade por parte do escravo em acumular alguma renda. É percebido na análise das fontes e no diálogo com as autoras, que essas dificuldades na formação integral do pecúlio não significavam para os escravos o abandono da luta pela conquista da liberdade, pelo contrário, se traduziam em negociações e arranjos dos mais diversos, por meio dos quais os escravos continuavam a buscar sua liberdade.

\section{A alforria em troca de bens, mercadorias ou escravos}

Outra forma encontrada pelos escravos para a compra da manumissão foram as trocas da liberdade por mercadorias ou bens que eles conseguiam acumular. Neste sentido, Pires analisa duas alforrias conquistadas por trocas:

Florêncio Preto de 25 annos de idade solteiro [lavrador] de José Moreira Barbosa ... Pagou pela sua liberdade não só a quantia de $150 \$ 000$ reis em dinheiro e também certas creações e alguns trenzinhos que ele possui, de minha muito livre vontade [...] (PIRES, 2006, p.158, grifo nosso). 
Theresa, crioula, 60 annos mais ou menos, que a houve por dote do finado meo sogro [...] a qual forro e assim forra fica de hora em diante sem condição, visto os bons serviços que me tem prestado e deixado produções para mim e meos herdeiros [...] João Fernandes de Souza. (PIRES, 2006, p.158, grifo nosso).

Em ambos os casos as formas de pagamento incluem pertences simples dos escravos, o que segundo a autora, revela a condição modesta dos senhores do alto sertão baiano. Estratégias semelhantes são percebidas em nossas fontes do Rio Grande do Sul:

Felipe; Crioulo; Sr. Manoel de Campos de Almeida; dt. conc. 03-07-24; dt. reg. 03-07-24 (Livro 7, p. 50r). Desc.: A carta foi concedida mediante o pagamento, pelo escravo, de 100 alqueires de trigo, no valor de 200\$, no ano de 1813, e por ter servido ao senhor durante 40 anos. O senhor declara que "sendo Deus Nosso Senhor servido privar-me a vista de ambos os olhos, não sei quando será servido levar-me da vida presente [...] por descargo de minha consciência", em razão disto, pediu a Rodrigo Fernandes Duarte que fizesse e assinasse a carta. $\mathrm{O}$ senhor era casado com Edivirges Joaquina de Almeida, com quem teve três filhos, "a saber 2 machos e 1 fêmea" (RIO GRANDE DO SUL, 2006, p.662, grifo nosso).

A análise da alforria do escravo Felipe revela ainda que, mesmo diante dos arranjos das formas de pagamento e sua efetivação, a liberdade por vezes ainda tardava. Neste caso, o pagamento foi realizado em mercadoria por Felipe no ano de 1813, sua liberdade só sendo lhe concedida, porém, onze anos depois, em 1824, em ocasião do débil estado de saúde do senhor.

Em uma sociedade escravista na qual, segundo Alencastro, o escravo era tributado, comprado, vendido, herdade, hipotecado, captado pela malha jurídica do Império ${ }^{8}$, em síntese, considerado uma propriedade ou mercadoria, as manumissões por vezes tinham como forma de pagamento outros escravos. Como apontado por Goldsmith, o escambo era praticado considerandose que a substituição de um escravo por outro não trouxesse danos ao patrimônio senhorial ${ }^{9}$.

Em nossas fontes, esta prática foi observada em vários casos. No caso do escravo Francisco, além da substituição de um escravo por outro, foi requerida a complementação do pagamento em dinheiro, como se observa:

Francisco; Crioulo do sertão de Pernambuco; Sr. José Pinto Martins; dt. conc. 16-12-22; dt. reg. 18-08-23; da Freguesia de São Francisco de Paula (Livro 7, p. 16r). Desc.: A carta foi concedia mediante a troca por outro escravo, de nome Joaquim (Benguela) e mais "2 doblas de volta, cujas ficam restando para me satisfazer da data deste a quatro meses, e de hoje

8 ALENCASTRO, 1997, p. 16.

9 GOLDSMITH, 2010, p. 118. 
em diante poderá tratar de sua vida como liberto". O senhor recebeu a quantia em 09-03-23, em Charqueada (RIO GRANDE DO SUL, 2006, p.662, grifo nosso).

Em outros casos, a alforria se efetivou mediante a troca simples de um escravo por outro:

Joaquim; preto; Mina; Sra. Rita Inácia de Jesus (viúva de Francisco José da Cunha) (Livro 10, p. 130v). Desc.: A carta foi concedida "pelos serviços prestados the dou a liberdade, recebendo em troca dele outro escravo, de nome Antônio Congo". A carta foi passada pelo filho e procurador da senhora e herdeiros (RIO GRANDE DO SUL, 2006, p.680, grifo nosso).

Francisca Maria da Conceição; preta; Cabinda; Sra. Maria Luiza da Silva Gomes; dt. conc. 08-04-39; dt. reg. 12-04-39 (Livro 12, p. 72r). Desc.: A carta foi concedida em razão da escrava "implorar a sua alforria" e ter dado em troca uma outra, de nome Teodora (mulata, Pernambuco), comprada de Manoel Teixeira Porto (RIO GRANDE DO SUL, 2006, p.674, grifo nosso).

Carolina; preta; Congo; Sr. Jacinto Roque Ferreira; dt. conc. 17-09-41; dt. reg. 20-09-41 (Livro 14, p. 32v). Desc.: A carta foi concedida "em virtude da minha escrava [...] me implorar a sua alforria, e para este efeito comprara a José da Costa Siqueira e Companhia uma escrava de nome Sara, nação Gege, que me deu em seu lugar com documento autêntico, por tal motivo e por ato de beneficência que quero despender com a sobredita minha escrava, por esta lhe concedo sua plena liberdade" (RIO GRANDE DO SUL, 2006, p.678, grifo nosso).

Em outro caso analisado, a manumissão da escrava Luíza foi paga mediante a entrega por parte de Sabá, sua mãe, ex-escrava, das casas que esta possuía e que é de se supor, com alto custo tenham sido conquistadas, considerando a dificuldade dos libertos em conquistar seu espaço em uma sociedade escravista:

Luíza; Sabá (sua mãe, preta, forra); Crioula; Sr. Matias José Velho; dt. conc. 11-08-51; dt. reg. 19-08-51 (Livro 17, p. 53v). Desc.: A carta foi concedida em razão de "nesta ocasião haver em resto de meu pagamento um documento de hipoteca das casas que a dita Sabá possui na Rua da Alfândega desta cidade, e por estar satisfeito passo a presente por mim feita e assinada" (RIO GRANDE DO SUL, 2006, p.667, grifo nosso).

A alforria de Luíza, além de nos revelar a respeito da troca de escravos por bens e serviços, nos permite observar a luta dos libertos pela extensão desta condição à sua família. 


\section{A compra da liberdade por terceiros}

Conforme Freire, as relações familiares tinham papel fundamental na luta pela liberdade dos escravos, que se ancoravam na perspectiva de uma vida melhor para eles e suas famílias. Para tanto, segundo o autor, os escravos não se furtavam da luta pela liberdade de suas mães, pais, filhos, avós, aqueles com quem iriam reconstruir suas vidas no mundo da liberdade. ${ }^{10}$ Este desejo de liberdade não apenas para si, como para a família, pode ser percebido na análise das fontes Sul-RioGrandenses, das quais destacamos a alforria das escravas Belmira e Catarina:

Belmira; Carlota (sua mãe, preta, Nagô, liberta em 14-12-52 pela mesma senhora); Crioula, 4; Sra. Emerenciana Maria do Rosário; dt. conc. 24-0653; dt. reg. 05-07-53 (Livro 17, p. 86r). Dec.: A carta foi concedida mediante o pagamento de $350 \$$ pela mãe da escrava. Por não saber ler nem escrever, a senhora pediu a Manoel Marques da Silva que a fizesse e assinasse a rogo (RIO GRANDE DO SUL, 2006, p.669, grifo nosso).

Maria; Catarina (sua mãe); Sra. Rita Maria de Alcântara; dt. conc. 15-0728; dt. reg. 13-09-28; da Freguesia de Canguçu (Livro 10, p. 33r). Desc.: $A$ carta foi concedida mediante o pagamento de 1 dobla, "atendendo aos bons serviços, e as súplicas, que me tem feito minha escrava Catarina [...] sou servida conceder a última filha que a minha escrava teve e por ora batizada em casa com o nome de Maria, esta carta de plena liberdade”. Por não saber ler nem escrever, a senhora pediu a João Pereira de Medeiros que a fizesse e assinasse a rogo (RIO GRANDE DO SUL, 2006, p.658, grifo nosso).

Em ambos os casos, a manumissão de Belmira e Catarina foram pagas por suas respectivas mães, uma delas liberta um ano antes da filha, a outra ainda na condição de escrava, o que nos reforça a tese de Freire, da expectativa dos escravizados pela reconstrução de suas vidas em liberdade acompanhados de suas famílias.

A criação de laços familiares, segundo Robert Slenes ${ }^{11}$, foi também parte da estratégia senhorial para assegurar a permanência do escravo em sua posse. Segundo o autor, a família escrava transformava o cativo em refém, tanto de seus anseios quanto do proprietário, à medida que a fuga individual significaria a perda do contato com os entes queridos.

Mas os laços sanguíneos não eram a única esperança para a alforria diante da impossibilidade do acúmulo do pecúlio por parte do escravo. Em nossas fontes também encontramos a libertação concedida por terceiros, como no caso da escrava recém-nascida Maria Delfina, liberta mediante o pagamento de seu valor realizado por sua madrinha:

10 FREIRE, 2011, p.223.

11 SLENES, 1997, p. 276. 
Maria Delfina; Crioula; recém nascida; Sra. Veridiana de Castro Feijó; dt. conc. 18-03-40; dt. reg. 06-08-40 (Livro 13, p. 39v). Desc.: A carta foi concedida mediante o pagamento de $700 \$ 400$ pela madrinha da escrava, em razão do "amor que lhe tenho", a qual foi feita na pia batismal (RIO GRANDE DO SUL, 2006, p.676, grifo nosso).

Outros exemplos são percebidos na alforria dos escravos Rafael e Florência, tendo sido Rafael liberto passados quase quatro anos do pagamento realizado pelo seu pai, o espanhol Inácio. Já a escrava Florência, que se encontrava grávida, foi liberta pelo preto forro Antônio Constantino Blanco, cujo documento não revela ser ou não o pai da criança gestada por Florência:

Rafael; Maria (sua mãe, Crioula, escrava do mesmo senhor) e Inácio da Rosa (seu pai, espanhol); pardo; 4; Sr. Damásio Vergara (e sua mulher, Ana Bernarda de Bittencourt); dt. conc. 17-01-23; dt. reg. 18-06-23; da Freguesia do Espírito Santo (Livro 7, p. 2r). Desc.: A carta foi concedida mediante pagamento de $51 \$ 200$ pelo pai do escravo, quando escravo Rafael tinha 6 meses de idade. Os senhores declaram morar há 30 léguas do Escrivão Público (RIO GRANDE DO SUL, 2006, p.662, grifo nosso).

Florência; Crioula; Sra. Agostinha Marcelina de Oliveira; dt. conc.19-1243; dt.reg. 03-10-48 (Livro 17 8v). Desc. A carta foi concedida mediante o pagamento de 1:000\$ pelo preto forro Antônio Constantino Blanco, em razão do "estado em que se acha [...] e grátis pelo filho ou filha que tenha de nascer". A carta só começaria ter vigor após dois meses do registro (RIO GRANDE DO SUL, 2006, p.663, grifo nosso).

Além das relações afetivas, a alforria custeada por terceiros por vezes possuía intenção menos nobre: a obrigação de gratidão e serviço do liberto àquele que o alforriava. $\mathrm{O}$ caso do escravo Francisco, alforriado pelo pagamento de Antônio Batista Ferreira Maldonado exemplifica tal condição, uma vez que sua liberdade se condiciona a servir Antônio por seis anos, para só então se tornar plenamente livre:

Francisco; preto; Cabinda; Sr. Visconde de Camamú; dt. conc. 08-07-44; dt. reg. 28-02-50; do Rio de Janeiro (Livro 17, p. 37r). Desc.: A carta foi concedida mediante o pagamento de $400 \$$ por Antônio Batista Ferreira Maldonado, a quem o escravo fica "obrigado a servir, acompanhar e prestar toda a obediência [...] por espaço de 6 anos a contar da data de hoje, e só depois de findo esse prazo poderá de então por diante considerar-se inteiramente forro e livre de todo cativeiro e conduzir-se para onde bem lhe parecer" (RIO GRANDE DO SUL, 2006, p.664).

Para compreender a dinâmica da relação entre senhores e escravos é importante também a 
análise de outra faceta deste processo: qualquer que seja a forma de pagamento pelo qual se buscava a manumissão, ela estava impreterivelmente sujeita à aprovação do senhor. Era a este quem competia decidir quanto à alforria ou não de seu escravo.

Não raramente, nossa análise das fontes encontrou indícios do estabelecimento de relações entre senhores e escravos, expressas em frases como "em atenção ao amor que a mesma lhe tinha", a prontidão com a qual a escrava "constantemente" serviu à senhora, "por ter dado de mamar a dois filhos meus", "por descargo de minha consciência", "atendendo aos bons serviços, e as súplicas".

A recorrência desses termos, mais do que apenas expressar a "benevolência", "gratidão" e "filantropia" do senhor, nos permite pensar como as relações entre senhores e escravos dependia constantemente dos arranjos dos escravos, da estratégia da resistência por meio da submissão, de aproximar-se do senhor, do estabelecimento de laços de confiança e amizade ${ }^{12}$, especialmente tendo sido a manumissão uma prática, até 1871 , não sancionada em lei, encontrando suas bases no direito costumeiro e portanto dependendo fortemente da disposição do senhor para cumpri-la.

\section{Entre o direito costumeiro e os silêncios da lei escrita: espaços de luta}

Em um artigo intitulado Sobre os silêncios da Lei: Lei costumeira e positiva nas alforrias de escravos no Brasil no século XIX, Manuela Carneiro da Cunha desmistifica o que ela chama de "um dos erros mais bem-sucedidos da história": a ideia de que o Estado mediava as relações entre senhores e escravos por meio de lei que garantiria o direito à manumissão por parte do escravo. ${ }^{13} \mathrm{~A}$ autora aponta que esta decisão sempre coube ao senhor, não tendo o Estado, até 1871, regulamentado a prática em lei, mas tendo sido este costume amplamente difundido entre a sociedade brasileira escravista.

Segundo Carneiro da Cunha, a questão não era que o Estado se opusesse à manumissão, antes, a autora mostrará que havia por parte do Estado o interesse em que a decisão pela liberdade do escravo competisse ao senhor, processo que colocaria aquele submisso a este, sob pena de não conquistar a liberdade, restando ao Estado por sua vez, a preocupação apenas com o controle dos pobres livres:

12Mas, tudo leva a crer que no alto sertão as alforrias incondicionais não foram destituídas de negociações entre senhores e escravos [...] Situação que não elimina as relações de amizade, afeto e gratidão que as cartas sugerem (PIRES, 2006, 163).

13 CARNEIRO DA CUNNHA, Manuela. "Sobre os silêncios da lei: lei costumeira e positiva nas alforrias de escravos no Brasil do século XIX”. In: Cultura com aspas e outros ensaios. São Paulo: Cosac Naify, 2009, p. 133. 
Competia à "responsabilidade paternal" do senhor o controle dos escravos como o dos filhos. Ao Estado, teoricamente, competia o dos libertos e dos livres. Ora, a categoria considerada, entre todas, perigosa nesse início do século XIX era sem dúvidas a da gente de cor que não era escrava (CARNEIRO DA CUNHA, 2009, p.144).

Além do interesse do Estado em "dividir" com senhores a tarefa do controle social dos negros, havia ainda a questão da primazia do direito de propriedade do senhor sobre seu escravo e da relação de dependência da qual o senhor se beneficiava, como aponta a autora:

A questão era política, e o parecer de 1854, da seção de Justiça do Conselho do Estado, o explicita: era duro, reconhecia, negar ao escravo o direito à alforria paga, mas razões de Estado o exigiam para que a escravidão não se tornasse mais perigosa do que era. Se, ao contrário, o escravo só pudesse receber sua liberdade das mãos de seu senhor, não só se ressalvava o direito de propriedade, mas não se prejudicaria o sentimento de obediência e subordinação do escravo para com o seu senhor, e a dependência em que dele devia ser conservado (Almeida 1870, $4^{\circ}$ Livro das Ordenações: I074). Trata-se, está dito em todas as letras nesse texto, da dependência pessoal (CARNEIRO DA CUNHA, 2009, p. 142).

De fato, até 1871 a manumissão não havia sido legalizada pelo Estado. Até esta data, o Estado só intervinha na relação entre senhores e escravos concedendo alforrias em situações excepcionais, como na Guerra da Independência da Bahia; na Lei de Exceção de 1835, onde após a revolta dos malês o governo promete alforria aos escravos delatores a fim de prevenir novos levantes; no Rio Grande do Sul com a promessa de alforria aos escravos desertores das forças de Bento Gonçalves; na Guerra do Paraguai; e em séculos anteriores na tentativa de controle do contrabando de diamantes e madeira, com a possibilidade de denúncia dos senhores por parte dos escravos.

A regulamentação da manumissão veio a partir do parágrafo $4^{\circ}$ da Lei $\mathrm{N}^{\circ} 2040$, a Lei do Ventre Livre, também conhecida como Lei Rio Branco, sancionada em 28 de setembro de 1781 pela Princesa Isabel - que dezessete anos mais tarde sancionaria a Lei Áurea, desfecho legal do processo de abolição da escravidão negra no Brasil, ainda que nem de longe tenha sido o fim da marginalização do negro na sociedade brasileira. O texto do referido parágrafo decreta:

Art. 4. ${ }^{\circ}$ É permitido ao escravo a formação de um pecúlio com o que lhe provier de doações, legados e heranças, e com o que, por consentimento do senhor, obtiver do seu trabalho e economias. O Governo providenciará nos regulamentos sobre a colocação e segurança do mesmo pecúlio. 
(...)

$\S 2 .^{\circ}$ O escravo que, por meio de seu pecúlio, obtiver meios para indenização de seu valor, tem direito a alforria. Se a indenização não for fixada por acordo, o será por arbitramento. Nas vendas judiciais ou nos inventários o preço da alforria será o da avaliação.

Como percebido por Motta \& Lopes (2015), a lei reconhecia o direito ao pecúlio, mas não deixava de relegar ao senhor o consentimento pela poupança do escravo. O arbitramento do valor em caso do não acordo, por sua vez, não necessariamente significava a decisão dos juízes pelo valor estabelecido pelo proprietário, podendo constituir-se também em outro espaço de luta por parte dos escravos, que diante da negativa dos senhores em estabelecer um valor plausível para a manumissão, viam-se diante da necessidade de recorrer à Justiça, como aponta Campos:

Movidos pelo desejo, e, muitas vezes, pela necessidade de criar uma situação mais justa, os cativos exploravam com inteligência o espaço institucional disponivel na busca de alternativas inexistentes na relação pessoal com seu proprietário. Atualmente, a historiografia reconhece a submissão e a subserviência como estratégias utilizadas pelos escravos para arrancar do senhor alguma vantagem. Quando tais alternativas não alcançavam êxito, o Judiciário convertia-se numa instância de enfrentamento e desgaste da vontade senhorial. De modo geral, os escravos tentavam estabelecer, previamente, um ajuste consensual pela alforria. Apenas ocasionalmente, quando de um impasse, requisitava-se a intervenção do Juízo da localidade (CAMPOS, 2006, p.3-4, grifo nosso).

A autora exemplifica o êxito de tal estratégia de luta no caso da escrava Iria:

Em março de 1872, a escrava Iria ingressou na Justiça sob alegação parecida. Além da avançada idade de 40 anos, sustentava a cativa que seus problemas gástricos e oftalmológicos, responsáveis por sua frágil saúde, eram incompatíveis com suas atividades de doméstica. Iria dizia não enxergar bem e não poder se expor ao calor constante característico de seu ofício de cozinheira. O Juiz acatou essas alegações e arbitrou um valor, condizente com as economias da escrava, para a compra de sua alforria (CAMPOS, 2006, p.3, grifo nosso).

Ainda que não oficializada antes de 1871, a prática da manumissão sobreviveu no sistema escravista brasileiro por meio do costume e sua cristalização em lei é fruto das lutas dos escravos, como aponta Sidney Chalhoub:

[...] em algumas de suas disposições mais importantes, como em relação ao pecúlio dos escravos e ao direito à alforria por indenização de preço, a lei do 
ventre livre representou o reconhecimento legal de uma série de direitos que os escravos vinham adquirindo pelo costume, e a aceitação de alguns dos objetivos das lutas dos negros. Na realidade, é possível interpretar a lei de 28 de setembro, entre outras coisas, como exemplo de uma lei cujas disposições mais essenciais foram "arrancadas" pelos escravos às classes proprietárias (CHALHOUB, 1990. P. 27).

Neste sentido, Manuela Carneiro da Cunha aponta que se até então a lei escrita não se pronunciava a favor da manumissão, a lei costumeira o fazia. A autora descreve um paradoxo entre a lei e o costume, no qual este último, de caráter informal, prevalecia sobre a primeira, sancionada pelo Estado, especialmente longe das cidades, uma vez que, segundo a autora, "a autoridade das leis escritas variava, era sabido, na razão inversa da distância dos centros urbanos" (2009, p.140). Se a eficácia da lei escrita era questionável neste contexto, a lei costumeira parecia percorrer o sentido inverso. Para Carneiro da Cunha, o costume contava com a sanção da opinião pública, de padres, homens da mesma classe do senhor e até da "gentinha" diante da qual o descumprimento do costume traria desprestígio ao senhor. Além do desprestígio, a autora aponta que o senhor temia a fuga ou suicídio do escravo a qual a alforria fosse negada, trazendo-lhe prejuízo financeiro.

De modo semelhante, Pires destaca no diálogo com Eduardo Silva, a força do costume na sociedade brasileira mesmo antes de 1871:

Eduardo Silva (1997, p.142) também esclarece que esse 'direito' foi conquistado antes mesmo da aprovação dessa lei, "que não precisou de um diploma legal específico, mas veio de carona, quase imperceptível, no bojo da chamada Lei do Ventre Livre". Afirma que, antes de legalizado o direito de manter pecúlio e o de comprar a própria liberdade ("conquistas antigas" em tempos ainda não precisados pela "ausência de pesquisa específica"), os senhores dificilmente ousariam enfrentar a indignação de um homem que batalhou tostão por tostão ("em suas horas vagas", segundo os costumes) para comprar a própria liberdade, sobretudo numa cidade como a Corte. Caso o fizesse, enfrentaria não apenas a revolta pessoal do escravo, que poderia fugir, ou, mais freqüentemente ainda, recusar-se a qualquer colaboração eficiente. Enfrentaria a desaprovação social aberta, a terrível língua grande do povo miúdo. Essa opinião pública, irreverente e severa, própria das "camadas baixas do povo", manifestar-se-ia fatalmente "com grande intensidade", expressando sua desaprovação ao senhor "por todos os meios" (PIRES, 2006, p.155).

A convergência entre as análises dos autores nos permite compreender a prevalência do direito costumeiro na relação entre senhores e escravos no Brasil do século XIX. O constante descumprimento da lei escrita e a eficácia do direito costumeiro se constituem em mais uma contradição na construção da sociedade brasileira, a exemplo do paradoxo citado por Alencastro 
(1997), de um país que buscava seguir os princípios liberais que predominavam na economia, política e sociedade europeia, mas se constituía em uma sociedade escravista.

Neste cenário contraditório os escravos encontraram alternativas de luta, como recorrer ao costume, reivindicando-o para a conquista da liberdade via manumissão, usando estratégias, como vimos, que incluem os mais variados modos de aquisição da alforria, "buscando brechas dentro do sistema escravista ${ }^{14}$ " e alternando estratégias de acomodação e resistência na luta pela conquista da liberdade.

\section{As várias outras formas de luta pela liberdade}

Cumpre salientar que a busca pela manumissão não foi a única estratégia utilizada pelos escravos na luta pela liberdade, tendo estes homens e mulheres por vezes recorrido a revoltas e rebeliões, como podemos perceber em Morel:

Os cativos desenvolveram inúmeras formas de resistência, individuais ou coletivas, como fugas, ataques, roubos ou assassinatos contra senhores e feitores, suicídios, pequenos e grandes quilombos, envolvimento com lutas políticas não deflagradas por escravos, entre outras (MOREL, 2003, p.4546).

Para Morel, houve uma proliferação de quilombos nas províncias brasileiras ao longo do século XIX, e se somados, possivelmente alcançariam um número maior de participantes do que Palmares ${ }^{15}$.

Porém, como aponta Marquese "logo após a derrota de Palmares, reduziram-se substancialmente as oportunidades de sucesso para as revoltas escravas e os grandes quilombos no Brasil"16, ainda que a atividade quilombola tenha se ampliado no século XVIII com o aumento do tráfico negreiro transatlântico. Segundo o autor, um dos motivos para a não repetição de uma revolta da magnitude de Palmares é justamente o aumento das alforrias, que fariam uma espécie de controle da quantidade de escravos africanos e dos libertos nascidos no Brasil, estes últimos, segundo o autor, sendo utilizados no controle dos escravos revoltosos, como nos episódios das rebeliões escravas na Bahia entre 1807 e 1835, sobre as quais Marquese dialoga com João José Reis:

A chave para compreender esse fracasso reside exatamente nas clivagens

14 Cf. FREIRE (2011, p.222).

15 MOREL, 2003, p.46.

16 MARQUESE, 2006, p.3. 
que separavam de forma radical os africanos escravizados de seus descendentes - negros e mulatos - nascidos no Brasil. Não houve participação destes últimos grupos nos levantes comandados pelos africanos escravizados na Bahia. Muito pelo contrário, como esclarece João José Reis: mulatos, cabras e crioulos forneciam o grosso dos homens empregados no controle e repressão aos africanos. Eram eles que faziam o trabalho sujo dos brancos de manter a ordem nas fontes, praças e ruas de Salvador, invadir e destruir terreiros religiosos nos subúrbios, perseguir escravos fugitivos através da província e debelar rebeliões escravas onde quer que aparecessem (MARQUESE 2006, p.15).

Marquese enfatiza ainda que a resistência escrava na década de 1880 foi fundamental para a abolição, mas que esta "não se valeu da experiência histórica da onda de levantes africanos que a Bahia vivenciou entre 1807 e 1835. Em uma frase: estas revoltas, apesar de sérias e violentas, não abalaram a ordem escravista brasileira" (idem, p.15). Portanto, para o autor, a experiência de luta dos escravos em busca da liberdade após Palmares, teria se dado de forma muito mais contundente na busca pela manumissão, processo este possibilitado pelas estratégias de negociação dos escravos com seus senhores.

Morel concorda com Marquese, quanto ao fato das revoltas escravas não terem abalado a ordem escravista, porém, o autor acrescenta que elas: causaram inegável pânico à população nãoescrava e imprimiram novos rumos à legislação repressiva, à perspectiva de imigração de estrangeiros e ao debate sobre medidas para a gradual extinção do tráfico e trabalho escravo (MOREL, 2003, p.56-57).

Para além das diversas estratégias de negociação da manumissão citadas anteriormente, das fugas e insurreições, João Reis e Eduardo Silva citam como a liberdade configurava-se das mais variadas formas, seja pela criatividade, inteligência ou azar:

Alguns procuram aproveitar conjunturas favoráveis [...] Outros esfalfavamse em serviços extras e depositavam suas economias, de tostão em tostão, na caderneta da Caixa Econômica. Outros... mais confiantes na boa estrela do que em cadernetas, arriscavam as economias em bilhetes de loteria e sonhavam com o prêmio da liberdade. Outros ainda, recorrem a expedientes ilícitos, como o roubo, ou espremem o cérebro em complicados planos (REIS \& SILVA, apud. PIRES, 2006, p.157).

\section{Considerações finais}

Como percebemos, onde esteve presente a figura do escravo, esteve também a luta pela liberdade. Os autores que pesquisaram as manumissões em localidades como o sertão da Bahia, 
Vitória no Espírito Santo e Juiz de Fora em Minas Gerais no mesmo século, encontram dados bastante parecidos com aqueles que verificamos no município de Rio Grande. Estas similaridades nas análises nos levam a perceber o desejo constante por parte dos escravos de reconstruírem suas vidas e de suas famílias na condição de libertos, desejo este apreendido na diversidade das estratégias construídas pelos escravos na busca pela alforria, desconstruindo a ideia do escravo como sujeito passivo, espectador de sua própria história, conformado a inexorabilidade de sua condição cativa.

Procuramos ainda discutir como a manumissão e o pecúlio, sancionados em lei apenas em 1871, já vinham sendo praticados na sociedade brasileira, inseridos no campo do direito costumeiro, o que faz com que sua cristalização na forma de lei seja percebida como uma conquista oriunda das lutas dos escravizados pela liberdade no Brasil. Inserida no campo do costume, condicionada à vontade do senhor, a conquista da alforria implicava na adoção, por parte dos escravos, de estratégias de aproximação, conquista de afeto e confiança, sujeição, e da constante negociação com seu senhor, demonstrando que por vezes o espaço de resistência encontrado pelo sujeito escravizado se constituía em estratégias que se assemelham à acomodação, mas longe estão a significar a conformação.

\section{Referências Bibliográficas}

ALENCASTRO, Luiz Felipe. História da vida privada no Brasil. São Paulo: Companhia das Letras, 1997.

CAMPOS, Adriana P. Escravidão e liberdade nas barras dos tribunais. São Paulo: Revista online do Arquivo Público do Estado de São Paulo. Ed. 9. 2006.

CARNEIRO DA CUNNHA, Manuela. Sobre os silêncios da lei: lei costumeira e positiva nas alforrias de escravos no Brasil do século XIX. In: Cultura com aspas e outros ensaios. São Paulo: Cosac Naify, 2009.

CHALHOUB, Sidney. Visões da liberdade: uma história das últimas décadas da escravidão na corte. São Paulo: Companhia das Letras, 1990.

FREIRE. JONIS. "Alforrias e tamanho das posses: possibilidades de liberdade em pequenas, médias e grandes propriedades do sudeste escravista (século XIX)”. In: Belo Horizonte: Varia História, vol. 27, n 45: p.211-232, jan/jun 2011

GOLDSMITH, Eliana R. A carta de alforria na conquista da liberdade. São Paulo: IDE, 2010.

LARA, Silvia H. "Escravidão, cidadania e história do trabalho no Brasil”. São Paulo: Projeto 
História, (16), fev. 1998.

MARQUESE, Rafael B. A dinâmica da escravidão no Brasil: resistência, tráfico negreiro e alforrias, séculos XVII a XIX. São Paulo: Novos Estudos, CEBRAP, 74, p. 107-123, Março de 2006.

MOREL, Marco. O periodo das regências (1831-1840). Rio de Janeiro: Jorge Zahar, 2003.

MOTTA, José F; LOPES, Luciana S. O pecúlio dos escravos: concessão ou conquista? Economia \& História: crônicas de histórica econômica, p. 22-28, Maio de 2015.

PIRES, Maria F. N. Cartas de alforria: "para não ter o desgosto de ficar em cativeiro". Revista Brasileira de História. São Paulo, v. 26, nº 52, p. 141-174 - 2006

REIS, João José; SILVA, Eduardo. Negociação e conflito: a resistência negra no Brasil escravista. São Paulo: Companhia das Letras, 1989.

RIO GRANDE DO SUL. Secretaria da Administração e dos Recursos Humanos. Departamento de Arquivo Público. Documentos da escravidão: Catálogo seletivo de cartas de liberdade acervo dos tabelionatos do interior do Rio Grande do Sul / - Porto Alegre: CORAG, 2006.

SLENES, Robert W. Senhores e subalternos no Oeste Paulista. In: ALENCASTRO, Luiz Felipe de (org.). História da vida privada no Brasil: Império. São Paulo: Companhia das Letras, 1997. $233-290$.

Recebido em 10/04/16 - Aprovado em 04/07/16 